\title{
Obesity-stimulated aldosterone release is not related to an S1P-dependent mechanism
}

\author{
Stephan Werth1, Helge Müller-Fielitz1,2 and Walter Raasch1,2,3 \\ ${ }^{1}$ Institute of Experimental and Clinical Pharmacology and Toxicology, University of Lübeck, Lübeck, Germany \\ ${ }^{2}$ CBBM (Center of Brain, Behavior and Metabolism), Lübeck, Germany \\ 3DZHK (German Centre for Cardiovascular Research), partner site Hamburg/Kiel/Lübeck, Lübeck, Germany
}

Correspondence should be addressed to W Raasch Email walter.raasch@pharma. uni-luebeck.de

\begin{abstract}
Aldosterone has been identified as an important factor in obesity-associated hypertension. Here, we investigated whether sphingosine-1-phosphate (S1P), which has previously been linked to obesity, increases aldosterone release. S1P-induced aldosterone release was determined in $\mathrm{NCI} \mathrm{H295R} \mathrm{cells} \mathrm{in} \mathrm{the} \mathrm{presence} \mathrm{of} \mathrm{S1P} \mathrm{receptor}$ (S1PR) antagonists. In vivo release of S1P $\left(100-300 \mu \mathrm{g} / \mathrm{kg}_{\mathrm{bw}}\right)$ was investigated in pithed, lean Sprague Dawley (SD) rats, diet-obese spontaneous hypertensive rats (SHRs), as well as in lean or obese Zucker rats. Aldosterone secretion was increased in $\mathrm{NCl} \mathrm{H295R} \mathrm{cells}$ by S1P, the selective S1PR1 agonist SEW2871 and the selective S1PR2 antagonist JTE013. Treatment with the S1PR1 antagonist W146 or fingolimod and the S1PR1/3 antagonist VPC02319 decreased baseline and/or S1P-stimulated aldosterone release. Compared to saline-treated SD rats, plasma aldosterone increased by $\sim 50 \mathrm{pg} / \mathrm{mL}$ after infusing S1P. Baseline levels of S1P and aldosterone were higher in obese than in lean SHRs. Adrenal S1PR expression did not differ between chow- or CD-fed rats that had the highest S1PR1 and lowest S1PR4 levels. S1P induced a short-lasting increase in plasma aldosterone in obese, but not in lean SHRs. However, 2-ANOVA did not demonstrate any difference between lean and obese rats. S1P-induced aldosterone release was also similar between obese and lean Zucker rats. We conclude that S1P is a local regulator of aldosterone production. S1PR1 agonism induces an increase in aldosterone secretion, while stimulating adrenal S1PR2 receptor suppresses aldosterone production. A significant role of S1P in influencing aldosterone secretion in states of obesity seems unlikely.
\end{abstract}

\section{Key Words}

- renin-angiotensisn system

- obesity

- steroids

- hypertension

- spingosine-1-phosphate

\section{Introduction}

The Framingham Offspring Study suggested that increased abdominal fat mass accounts for $65-75 \%$ of the risk for hypertension (Garrison et al. 1987). Among other hormonal systems, the renin-angiotensinaldosterone system (RAAS) has been established as a major determinant of obesity-induced hypertension (Rahmouni et al. 2005). The RAAS is activated in the fat tissue of obese rats and humans (Giacchetti et al. 2002, Boustany et al. 2004, Engeli et al. 2005). Accordingly, ACE is upregulated in adipocytes (Bloem et al. 1995, Cooper et al. 1998, Karlsson et al. 1998), and obese individuals demonstrate elevated circulating angiotensin II (AngII) levels (Harte et al. 2005). In contrast, weight loss not only normalizes enzyme activity of the RAAS but 
also attenuates blood pressure (Engeli et al. 2005). The potency of $\mathrm{AT}_{1}$ receptor blockers to lower body weight particularly in obese individuals and the findings that body weight of double $\mathrm{AT}_{1 \mathrm{~A}} / \mathrm{AT}_{1 \mathrm{~B}}$ receptor knockout mice is lower than in wild-type controls further strengthen the functional cross-talk among weight, blood pressure regulation and RAAS activity (Gembardt et al. 2008, Müller-Fielitz et al. 2015).

Aldosterone is the second key player of the RAAS. Aldosterone production in zona glomerulosa (ZG) cells is regulated by distinct extracellular stimuli (potassium, AngII, ACTH) via $\mathrm{Ca}^{2+}$ mobilization following cAMPdependent (ACTH) or -independent (AngII, potassium) mechanisms. Aldosterone plasma levels positively correlate with fat mass in obesity (Lamounier-Zepter et al. 2006, Krug \& Ehrhart-Bornstein 2008) and with obesityinduced hypertension (Kidambi et al. 2007). The following findings indicate that aldosterone excess is not an epiphenomenon to higher AngII levels, but rather results from adrenal hypersensitivity to AngII among overweight individuals: (1) AngII-mediated aldosterone secretion was higher in obese than in lean individuals (BentleyLewis et al. 2007, Müller-Fielitz et al. 2012b); (2) adipocytes secrete mineralocorticoid-releasing factors (MRFs), which themselves enhance aldosterone release independently of AngII (Ehrhart-Bornstein et al. 2003, 2004); (3) adipocytes sensitize adrenocortical cells to AngII via ERK1/2dependent upregulation of steroidogenic acute regulatory (StAR) protein (Krug et al. 2007); (4) ZG growth and the expression of aldosterone synthase and $\mathrm{AT}_{1 \mathrm{~B}}$ receptors were selectively heightened in obesity under concomitant AngII stimulation, which further enhanced circulating aldosterone levels and augmented blood pressure response to AngII (Müller-Fielitz et al. 2012b); and (5) the rise in blood pressure after chronic AngII stimulation was diminished in adrenalectomized obese Zucker rats in which plasma aldosterone levels could only be scarcely detected (Müller-Fielitz et al. 2012b).

However, MRFs are still being identified, including at least two that differ in heat sensitivity and molecular mass (< or $>50 \mathrm{kDa}$ ) (Ehrhart-Bornstein et al. 2003, 2004). Based on observations that plasma LDL is increased in hypertensive obese patients, Ehrhart-Bornstein's group also showed that LDL dramatically increased aldosterone release in human adrenocortical NCI H295R cells. Thus, aldosterone excess in hypertensive individuals may partially result from elevated LDL levels. However, it was speculated that other MRFs may also be involved (Lamounier-Zepter et al. 2006). Since the identified MRF was shown to increase aldosterone release via
ERK1/2-dependent upregulation of StAR activity (Krug et al. 2007) and S1P induces both StAR mRNA expression and ERK1/2 activation (Brizuela et al. 2007, Lucki et al. 2012), we hypothesized that S1P acts as an MRF. The molecular mass of S1P is $<50 \mathrm{kDa}$ and it is heat-sensitive $\left(>99^{\circ} \mathrm{C}\right)$, both thought to be essential features of MRF (LamounierZepter et al. 2006). S1P is a bioactive sphingolipid and interacts with its particular $G_{i}$ protein-coupled receptors, termed S1PR1-5 (Maceyka \& Spiegel 2014, Proia \& Hla 2015). S1PRs are highly expressed in the human adrenal gland (Wang et al. 2014). S1P interacts not only in cellular processes of immunity, inflammation and inflammatory disorders (Maceyka \& Spiegel 2014, Proia \& Hla 2015), but is also involved in cardiovascular and metabolic functions (Bellini et al. 2015, Borodzicz et al. 2015). Interestingly, there is clear evidence that S1P levels are higher in plasma and adipose tissue of obese subjects than in lean individuals (Samad et al. 2006, Blachnio-Zabielska et al. 2012a, Kowalski et al. 2013), thus supporting the hypothesis that S1P may indeed be the missing link between obesity and hypertension due to adrenal hypersensitization. Thus, we hereby aimed to investigate whether S1P stimulates aldosterone release in a human adrenocortical cell line and, if so, which S1PR would be involved. Furthermore, S1P-induced aldosterone release was expected to be higher in obese than in lean rats.

\section{Materials and methods}

\section{Animals}

The study was carried out according to the National Institutes of Health guidelines for the care and use of laboratory animals. Animal care and experimental procedures were approved by the ethics committee of the local regulatory authority. Male SD rats, SHRs and lean and obese Zucker rats were used in the experiments (all from Charles River, Sulzberg, Germany). The animals were kept at room temperature with a 12-h/12-h dark (14:0002:00 h)/light (02:00-14:00 h) cycle.

\section{Preparation of S1P stock solution}

S1P was obtained from Avanti Polar Lipids (Alabaster, AL, USA). A methanolic S1P stock solution was prepared. $\mathrm{S} 1 \mathrm{P}(0.5 \mathrm{mg} / \mathrm{mL})$ was added to a methanol/water mixture $(95 / 5)$, heat-mixed $\left(50^{\circ} \mathrm{C}\right)$ and sonicated until S1P was suspended. Subsequently, $100 \mu \mathrm{L}$ aliquots of this mixture were stored $\left(-20^{\circ} \mathrm{C}\right)$ in glass tubes. For usage,

Published by Bioscientifica Ltd 
aliquots were warmed up to room temperature and the methanol/water were evaporated under nitrogen flow. The dry residue was dissolved in saline $(0.9 \%)$, supplemented with bovine serum albumin (BSA, $4 \mathrm{mg} / \mathrm{mL}$ ).

\section{Cell culture}

In vitro assays of S1P-induced aldosterone release were performed by using the human adrenocortical carcinoma NCI H295R cell line. Only cells originating from the 4th to 20th passage were used. In accordance with previous work, cells were grown in $20 \mathrm{~mL}$ Dulbecco's Modified Eagle Medium/Ham's F12 (DMEM/F12; from VWR International, Darmstadt, Germany) containing $15 \mathrm{mmol} / \mathrm{L}$ HEPES and $2.5 \mathrm{mmol} / \mathrm{L}$ L-glutamine, supplemented with $1.125 \mathrm{~g} / \mathrm{L}$ $\mathrm{NaHCO}_{3}$, insulin $(66 \mathrm{nmol} / \mathrm{L})$, hydrocortisone $(10 \mathrm{nmol} / \mathrm{L})$, $17 \beta$-estradiol $(10 \mathrm{nmol} / \mathrm{L})$, transferrin $(10 \mathrm{mg} / \mathrm{mL})$, selenite $(30 \mathrm{nmol} / \mathrm{L})$, penicillin $(100 \mathrm{U} / \mathrm{mL})$, streptomycin $(100 \mathrm{mg} / \mathrm{mL})$ and $2 \%$ fetal bovine serum (Krug et al. 2007). NCI H295R cells were grown in $75-\mathrm{mL}$ flasks at $37^{\circ} \mathrm{C}$ in a humidified $\mathrm{CO}_{2} / \mathrm{O}_{2}$ atmosphere (5\%/95\%). The medium was changed every 2 days, and cells were subcultured every 7 days using Accutase (PAA Laboratories, Pasching, Austria) for cell detachment. The cell suspension was centrifuged $\left(70 \mathrm{~g}, 6 \mathrm{~min}, 21^{\circ} \mathrm{C}\right)$, and the cell pellet was then incubated with $100 \mu \mathrm{L}$ AccuMax (PAA Laboratories) and resuspended with medium to achieve a cell density of 75000 cells $/ \mathrm{mL}$. Of this cell suspension, $2 \mathrm{~mL}$ was used for subculture in $75-\mathrm{mL}$ flasks containing $20 \mathrm{~mL}$ medium. For experiments, $500-\mu \mathrm{L}$ portions of the cell suspension (and $500 \mu \mathrm{L}$ additional medium) were incubated in 24-well culture plates for $96 \mathrm{~h}$. After $95 \%$ cell confluence was reached, the cells were used for experiments.

\section{Aldosterone release from the human adrenocortical carcinoma cell line $\mathrm{NCl}-\mathrm{H} 295$}

Cells were purged with PBS buffer (PAA Laboratories) twice and then $500 \mu \mathrm{L}$ medium supplemented with $0.01-10 \mu \mathrm{M}$ S1P, 0.1-30 $\mu \mathrm{M}$ SEW2871 (Tocris, Wiesbaden, Germany), $1-30 \mu \mathrm{M}$ FTY720 (Tocris), $20 \mu \mathrm{M}$ forskolin (SigmaAldrich) or $0.01-10 \mu \mathrm{M}$ AngII was added. To confirm $\mathrm{AT}_{1}$ receptor specificity for AngII-induced aldosterone release, additional experiments were performed in the presence of $10 \mu \mathrm{M}$ losartan. S1PR specificity in aldosterone release was determined by preincubation with the S1PR1 antagonist W146 $(10 \mu \mathrm{M}$, Tocris), the S1PR2 antagonist JTE013 $(10 \mu \mathrm{M}$, Tocris) and the S1PR1/3 antagonist VPC02319 $(10 \mu \mathrm{M}$, Avanti Polar Lipids) or a combination of the aforementioned receptor ligands. Control experiments were performed without S1P antagonists. After 30-min preincubation, medium was removed and $500 \mu \mathrm{L}$ fresh medium containing the appropriate S1P antagonist and $10 \mu \mathrm{M}$ S1P or vehicle was added. After $24 \mathrm{~h}$, medium was collected and stored at $-20^{\circ} \mathrm{C}$ until aldosterone analyses. Cells were washed twice with $500 \mu \mathrm{L}$ PBS buffer and also stored at $-20^{\circ} \mathrm{C}$ until protein was quantified according to Lowry.

\section{Pithed rat preparation}

Studies on aldosterone response to S1P were performed in a 'pithed rat' model, to only consider vascular reactivity to S1P for blood pressure effects. Rats were pithed at the beginning of the light cycle as previously described (Raasch et al. 2003, Müller-Fielitz et al. 2012b). Briefly, animals were anesthetized with ether and artificially respirated. The medulla and thoracolumbar portions of the spinal cord were destroyed using a steel pithing rod. Catheters were placed into a carotid artery and both femoral veins. Both vagal nerves were severed. Blood pressure was measured via the carotid catheter. After preparation, pithed rats were allowed to recover for approx. $1 \mathrm{~h}$ until blood pressure and heart rate were constant. Thereafter, S1P was injected.

\section{S1P effects on plasma aldosterone in pithed SD rats}

S1P was intravenously injected as a bolus within $30 \mathrm{~s}$ (100 or $200 \mu \mathrm{g} / \mathrm{kg}$ ). Then, $1 \mu \mathrm{g}$ was injected per kg body weight. S1P stock solutions were prepared as described earlier and further diluted to final concentrations with BSA ( $4 \mathrm{mg} / \mathrm{mL}$ in saline) in glass vessels by vortexing $\left(30 \mathrm{~min}, 37^{\circ} \mathrm{C}\right)$. Control animals only received vehicle. At baseline and 3, 5, 10, 15 and 20 min after injections, $200-\mu \mathrm{L}$ blood samples were drawn via the femoral vein catheter to determine plasma aldosterone and blood glucose levels. Volume depletion was compensated by infusing hydroxyethyl starch (6\%; Fresenius, Homburg, Germany) over 30 s. For control experiments, additional SD rats received AngII (10 or $30 \mu \mathrm{g} / \mathrm{kg}$ ) and blood samples were acquired in the same manner for aldosterone and glucose analyses. After the experiments, rats were euthanized by decapitation.

\section{S1P effects on plasma aldosterone of diet-induced obese, pithed rats}

Aldosterone release was also investigated in a nongenetic obese rat model. Here, SHRs ( $n=12$ in each group) were

Published by Bioscientifica Ltd. 
fed with a high-caloric cafeteria diet (various chocolate/ cookie bars) for 42 weeks. The diet was abundantly offered, supplementary to chow, whereas controls received chow only (Miesel et al. 2010). At regular intervals, blood pressure and heart rate were determined by plethysmography (Raasch et al. 2002) and blood samples were withdrawn from a tail nick to measure blood glucose, plasma aldosterone and S1P levels. For S1P-induced aldosterone release, $200 \mu \mathrm{g} / \mathrm{kg}$ S1P was intravenously injected as described earlier in chow- vs CD-fed SHRs. Procedures for blood sampling and determining aldosterone and glucose levels were similar to the protocol used in SD. After decapitation, adrenals were harvested for S1PR mRNA quantification.

\section{S1P effects on plasma aldosterone in lean and obese Zucker rats}

One hour after rats had been pithed, vehicle $\left(1 \mu \mathrm{L} / \mathrm{kg}_{\mathrm{bw}}\right)$ was injected. A $200-\mu \mathrm{L}$ blood sample was drawn before and 3, 5, 10 and $15 \mathrm{~min}$ later. Then, 20, 40 and $60 \mathrm{~min}$ after administering vehicle, we repeatedly injected S1P at increasing doses $\left(100,200\right.$ and $300 \mu \mathrm{L} / \mathrm{kg}_{\mathrm{bw}}$, respectively). Again, $200 \mu \mathrm{L}$ blood was sampled 3, 5, 10 and $15 \mathrm{~min}$ after each S1P injection. Each blood withdrawal was compensated by an infusion of $200 \mu \mathrm{L}$ hydroxyethyl starch (6\%; Fresenius, Homburg, Germany) over 30 s.

\section{Biochemical analysis}

Plasma concentrations of aldosterone (07-108202, MP Biomedicals, Germany), corticosterone (07-120103, MP Biomedicals, Germany) and AngII (ED29051, IBL, Germany) were determined by radioimmunoassays. Assays were performed as recommended by the manufacturer. Blood glucose was determined using glucose sensors (Ascensia ELITE, Bayer, Leverkusen, Germany).

\section{RNA isolation and CDNA synthesis}

Total RNA from one adrenal was extracted on the ABI PRISM 6100 Nucleic Acid PrepStation (Applied Biosystems). The amount of total RNA was determined using a RiboGreen RNA quantitation assay (Invitrogen). Isolation of genomic DNA was avoided by thorough treatment with DNase I. First-strand cDNA was synthesized using oligo-(dT) 15 primer and AMV reverse transcriptase (Invitrogen). cDNA was stored at $-20^{\circ} \mathrm{C}$ until further analysis.

\section{Quantitative real-time PCR (qPCR)}

mRNA levels were quantified by quantitative realtime polymerase chain reaction using SYBR Green reagent (Invitrogen) on an ABI Prism 7000 platform (Applied Biosystems) according to established, standard protocols and using primers for S1PR1 (sense: 5'-GCATCCCAGTGGTTAAGGCT-3, antisense: 5'-TCCTGCTAACAGGTCCGAGA-3), S1PR2 (sense: 5'-CTTCATCACGCTCTCTGCCT-3, antisense: 5'-GCCACCCAGAATCAGCGATA-3), S1PR3 (sense: 5'-CAGATGAGCCTTGC AGAACG-3, antisense: 5'-AGTATCATTCCCCAAGACTGGC-3), S1PR4 (sense: 5'-CATTGG GACAAGCAACCTGC-3, antisense: 5'-CTGTGTGGTTCGCAGCTGTA-3) and S1PR5 (sense: $\quad 5$ '-gtgctcccgtggacatctggcagga-3, antisense: 5 -caggttctccagcacgatga-3). All primers were obtained from Invitrogen.

\section{Determination of S1P in plasma of DIO rats}

S1P was quantified in plasma according to a modified method of Butter (Butter et al. 2005) after liquid/liquid plasma extraction; then, reversed-phase isocratic HPLC was performed with a precolumn derivatization with o-phthalaldehyde (OPA) and fluorescence detection (ex/em 340/455 nm). For S1P extraction, a $100-\mu \mathrm{L}$ plasma sample (or spiked standard samples) was diluted with $100 \mu \mathrm{L}$ methanol (containing 100 ng/mL C17-S1P (Avanti Polar Lipids) as internal standard) and $900 \mu \mathrm{L} \mathrm{NaCl}$ $(1 \mathrm{mmol} / \mathrm{L})$ and was mixed with $10 \mu \mathrm{L} \mathrm{HCl}(37 \%)$ and $3000 \mu \mathrm{L}$ dichlormethane/2-propanol (1/1) in an 8-mL glass tube for $10 \mathrm{~min}$. Afterward, the mixture was centrifuged $\left(15 \mathrm{~min}, 2000 \boldsymbol{g}, 19^{\circ} \mathrm{C}\right)$. The aqueous phase was discarded and $2 \mathrm{~mL}$ of the organic phase was dried under nitrogen evaporation. The dry residue was resolved with $400 \mu \mathrm{L}$ of the mobile phase. An aliquot of $50 \mu \mathrm{L}$ was mixed for $30 \mathrm{~min}$ with $300 \mu \mathrm{L}$ mobile phase and $20 \mu \mathrm{L}$ OPA reagent. The OPA reagent contained $100 \mu \mathrm{L}$ OPA stock solution $(50 \mathrm{mg}$ in $5 \mathrm{~mL}$ ethanol), $5 \mu \mathrm{L}$ mercaptoethanol and $5 \mathrm{~mL} 500 \mathrm{mM}$ borate buffer ( $\mathrm{pH}$ 10.4). Subsequently, $20 \mu \mathrm{L}$ was injected onto the columns (LUNA C18(2), $3 \mu \mathrm{m}, 75 \times 4.6 \mathrm{~mm}$, Phenomenex, Aschaffenburg, Germany) at $40^{\circ} \mathrm{C}$ by using a mixture of $220 \mathrm{~mL} \mathrm{~K}_{2} \mathrm{HPO}_{4}(0.07 \mathrm{~mol} / \mathrm{L}, \mathrm{pH} 7.2)$ and $780 \mathrm{~mL}$ methanol as mobile phase (flow rate: $0.6 \mathrm{~mL} / \mathrm{min}$ ). Each sample was derivatized in triplicate with OPA and injected into the HPLC system. Means were included in the evaluations. Peak areas of chromatograms were considered for calculating individual plasma concentrations by using

Published by Bioscientifica Ltd 
the method of external standards of S1P. Linearity between peak area and concentrations of S1P were assured within a concentration range of $3.25-200 \mathrm{ng} / \mathrm{mL}$. Standard curves were determined in triplicate within a concentration range of $3.25-200 \mathrm{ng} / \mathrm{mL}$ to assure precision and reproducibility during measurements. Slopes $(13583 \pm 66)$ and goodness of curve fitting $(r=0.9994 \pm 0.0002)$ did not differ between each standard curve.

\section{Calculations and statistics}

Means and upper and lower quartiles are depicted as boxplots. Whiskers indicate variability between the 10th and 90th percentiles. In line graphs and tables, data are expressed as means \pm S.E.M. Differences were considered to be statistically significant at $P<0.05$.

In cell culture experiments, each experiment yielded 3-6 values for each stimulation condition. Each experiment was independently conducted thrice $(n=3)$. Means were calculated from the values of each condition for every experiment separately and were normalized for mean basal secretion. Data are presented as means of three independent repetitions. Groups were compared using paired $t$-test ( 2 groups) or one-way randomized-block ANOVA with subsequent Bonferroni's test for multiple comparisons as post hoc test ( $>2$ groups). Concentration response curves were calculated by GraphPad Prism 5 for Windows by nonlinear regression analyses using individual means. Results are presented as $\mathrm{EC}_{50}$ or $\mathrm{IC}_{50}$ values including 95\% confidence intervals.

For in vivo experiments, statistical analysis was performed by ANOVA, followed by appropriate post hoc tests (Bonferroni or Dunnett). Wilcoxon Signed-Rank test was used when variances differed significantly between groups. A 2-ANOVA, followed by Bonferroni's or Dunnett's post hoc test for multiple comparisons, was performed to examine the effects of two variables. All correlation analyses were performed by the two-tailed Pearson test.

\section{Results}

\section{Aldosterone release from the human adrenocortical carcinoma cell line $\mathrm{NCI}$ H295R}

AngII dose dependently enhanced aldosterone release from NCI H295R. Losartan blocked AngII-induced effects in aldosterone, confirming the $\mathrm{AT}_{1}$-dependent mechanism (Fig. 1A). As a second control, aldosterone release was demonstrated to be increased by forskolin (Fig. 1B and C).
Aldosterone release was also increased by S1P (Fig. 1B) and S1PR1 agonist SEW2871 (Fig. 1C) in concentrations $>3 \mu \mathrm{M}$. However, the magnitude of the secretion rate was lower than for AngII or forskolin. In contrast, inverse S1PR1 agonist FTY720 dose dependently attenuated aldosterone release by approx. 60\% (Fig. 1D). To discover which S1PR might be involved, aldosterone release from NCI H295R was determined in the presence of various S1P antagonists under baseline conditions and costimulations with S1P. The specific S1P1 antagonist W146 inhibited aldosterone release in the presence or absence of S1P (Fig. 2A). In contrast, aldosterone release was enhanced by the S1PR2 antagonist JTE013 independently of costimulation with S1P (Fig. 2B). VPC02319 was also supposed to lower aldosterone release, although secretion only tended to be reduced in the presence of S1P (Fig. 2C). The combination of VPC02319 and JTE013 reduced aldosterone release below baseline conditions. Since aldosterone secretion in the presence of S1P exceeded secretion at baseline conditions despite the double blockade VPC02319 and JTE013, we presume that S1PR4 or S1PR5 is involved in aldosterone release (Fig. 2D).

\section{In vivo effects of S1P on plasma aldosterone}

Baseline aldosterone levels were similar for controls and SD rats that were treated with $100 \mu \mathrm{g} / \mathrm{kg}_{\mathrm{bw}}$ S1P $(205 \pm 19$ vs $192 \pm 24 \mathrm{pg} / \mathrm{mL}, P>0.05$ ), but slightly lower in rats that were treated with $200 \mu \mathrm{g} / \mathrm{kg}_{\mathrm{bw}}$ S1P $(211 \pm 19$ vs
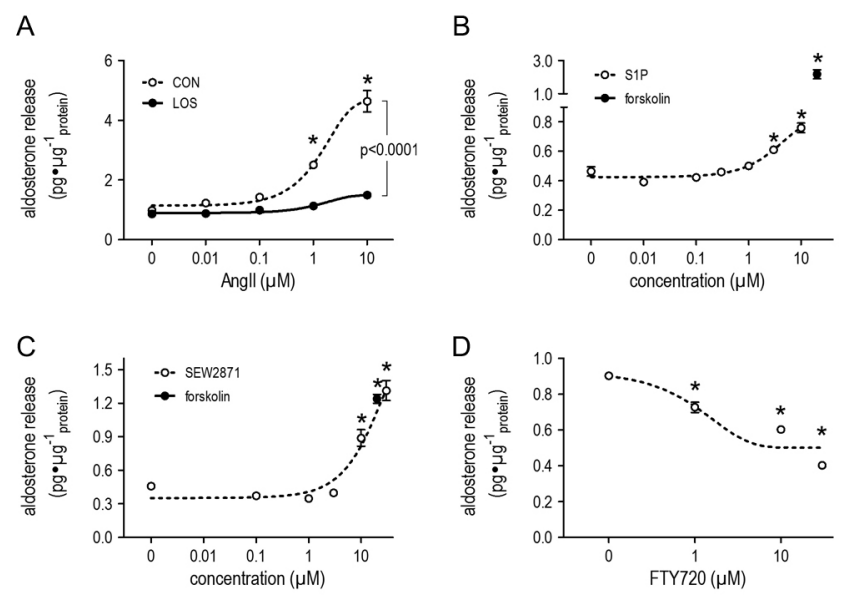

Figure 1

Aldosterone release in response to $24 \mathrm{~h}$ of incubation with Angll $(\mathrm{A}, n=4)$, S1P (B, $n=9)$, S1PR1-agonist SEW $2871(\mathrm{C}, n=9)$ and FTY720 $(\mathrm{D}, n=8)$ in $\mathrm{NCl} \mathrm{H} 295 \mathrm{R}$ cells. Forscolin $(\mathrm{FC}, 20 \mu \mathrm{M})$ was used as a positive control. Means \pm S.E.M., ${ }^{*} P<0.05$ vs controls tested by ANOVA and Bonferroni's (A: PAngll $<0.0001$, D: $P^{\mathrm{FTY} 720}<0.0001$ ) or Wilcoxon SignedRank Test $(B, C)$.

Published by Bioscientifica Ltd 
A



C



B



D



Figure 2

Effects of S1PR1 antagonist W146 (A, Ptreatment 2-way ANOvA $_{\text {< }}$ 0.0001), S1PR2 antagonist JTE013 (B, Ptreatment ${ }_{2 \text {-way ANOVA }}<0.0001$ ), S1PR1/3 antagonist VPC02319 (C, Ptreatment 2 -way ANOVA $=0.0011)$ and the combination of VPC02319 and JTE013 (D, Ptreatment ${ }_{2 \text {-way ANOvA }}<0.0001$ ) on aldosterone release in NCI H295R cells in the presence or absence of S1P (0 vs $10 \mu \mathrm{M})$. $P$-Values given in the figures originated from 2-ANOVA by testing the S1P effects. $P$-Values given in legends originated from 2-ANOVA by testing the effect of the antagonists. Bonferroni's post hoc test for multiple comparisons was only performed if $\mathrm{F}$ reached $P<0.05$ and there was no significant variance inhomogeneity. ${ }^{*} P<0.05$ vs controls tested by Bonferroni's post hoc test.

$132 \pm 20 \mathrm{pg} / \mathrm{mL}, P<0.05)$. In response to $200 \mu \mathrm{g} / \mathrm{kg}_{\mathrm{bw}} \mathrm{S} 1 \mathrm{P}$, plasma aldosterone increased by approx. $50 \mathrm{pg} / \mathrm{mL}$ during the observation period of $20 \mathrm{~min}$, whereas aldosterone levels of saline-treated SD tended to be decreased (Fig. 3B). This was not observed at $100 \mu \mathrm{g} / \mathrm{kg}_{\mathrm{bw}} \mathrm{S} 1 \mathrm{P}$ (Fig. 3A). Using 10 or $30 \mu \mathrm{g} / \mathrm{kg}_{\mathrm{bw}}$ AngII as a positive control, a marked and long-lasting rise in plasma aldosterone in response to AngII was noted. Both AngII doses had almost the same effects (Fig. 3C). Serving as controls to demonstrate adrenal reactivity, we additionally determined corticosterone levels in AngII-treated SD rats. Baseline levels of corticosterone prior to AngII (10 or $30 \mu \mathrm{g} / \mathrm{kg}_{\mathrm{bw}}$ ) were within the normal range $(155 \pm 31$ and $168 \pm 28 \mathrm{ng} / \mathrm{mL})$. In response to 10 or $30 \mu \mathrm{g} / \mathrm{kg}_{\mathrm{bw}}$ AngII, corticosterone increased within $20 \mathrm{~min}$ to $382 \pm 27(10 \mu \mathrm{g} / \mathrm{mL}, P<0.05$ vs baseline $)$ and $361 \pm 23 \mathrm{ng} / \mathrm{mL}(30 \mu \mathrm{g} / \mathrm{mL}, P<0.05$ vs baseline), which is in line with previous findings (Sowers et al. 1981). Blood glucose in SD rats was within the normal baseline range, independently of treatment regimen (saline vs $100 \mu \mathrm{g} / \mathrm{kg}_{\mathrm{bw}} \mathrm{S} 1 \mathrm{P}(78.7 \pm 1.5$ vs $76.8 \pm 2.5 \mathrm{mg} / \mathrm{dL})$, saline vs $200 \mu \mathrm{g} / \mathrm{kg}_{\text {bw }}$ S1P $(88.2 \pm 3.0$ vs $87.1 \pm 2.0 \mathrm{mg} / \mathrm{dL})$ or 10 vs $30 \mu \mathrm{g} / \mathrm{kg}_{\text {bw }}$ AngII $(77.1 \pm 3.6$ vs $79.4 \pm 3.5 \mathrm{mg} / \mathrm{dL})$ ). While glucose was not affected by S1P, glucose increased after AngII, not showing any differences between low and high AngII treatments (Fig. 3). Conspicuously, mean arterial


Figure 3

Effects of $100 \mu \mathrm{g} / \mathrm{kg}_{\mathrm{bw}}$ S1P (A), $200 \mu \mathrm{g} / \mathrm{kg}_{\mathrm{bw}}$ S1P (B) or Angll (C) on aldosterone $\left(\mathrm{S}_{1} \mathrm{P}_{200}\right.$ : Ptime $_{2 \text {-way }}$ ANOva $=0.001$, Angll: $P_{\text {time }}$ 2-way ANOVA $\left.<0.0001\right)$, MAP or glucose in pithed SD rats. Means and upper and lower quartiles are depicted as boxplots. Whiskers indicate variability between the 10th and 90th percentiles. In line graph, data are expressed as means \pm s.E.M. $P$-Values given in the figures originated from 2-ANOVA by testing the diet effects. $P$-Values given in legends originated from 2-ANOVA by testing the time effect. Bonferroni's post hoc test for multiple comparisons test was only performed if $\mathrm{F}$ reached $P<0.05$ and there was no significant variance inhomogeneity. ${ }^{*} P<0.05$ vs controls tested by Bonferroni's post hoc test, ${ }^{+} P<0.05$ vs before injection.



ublished by Bioscientifica Ltd.

http://joe.endocrinology-journals.org DOI: 10.1530/JOE-16-0550
(C) 2017 Society for Endocrinology Printed in Great Britain 
pressure (MAP) decreased slightly, but significantly $20 \mathrm{~ms}$ after injecting S1P (approx. $5 \mathrm{mmHg}$ ), followed by a sharp increase of $25 \mathrm{mmHg}\left(100 \mu \mathrm{g} / \mathrm{kg}_{\mathrm{bw}} \mathrm{S} 1 \mathrm{P}\right)$ and $40 \mathrm{mmHg}$ $\left(200 \mu \mathrm{g} / \mathrm{kg}_{\mathrm{bw}} \mathrm{S} 1 \mathrm{P}\right)$, respectively, $15 \mathrm{~ms}$ later, thus serving as a positive control for S1P function. These diametral effects on blood pressure may be related to different mechanisms since S1P activates vasorelaxation via an eNOS/NO-dependent pathway in endothelial cells and vasoconstriction mediated by RhoA/ROK pathways in smooth muscle cells (Igarashi \& Michel 2009). In response to AngII, MAP greatly increased compared to baseline state. Indeed, $30 \mu \mathrm{g} / \mathrm{kg}_{\mathrm{bw}}$ AngII was slightly more potent than $10 \mu \mathrm{g} / \mathrm{kg}_{\mathrm{bw}}$ AngII.

When SHRs were fed with $\mathrm{CD}$, the energy intake markedly increased, resulting in obesity and hyperglycemia (Fig. 4). While heart rate is consistently higher in CD- than in chow-fed SHRs, blood pressure remained almost the same (Fig. 4). At week 28, blood pressure in CD-fed animals tended to be higher than in chow-fed rats $(P=0.063)$. Plasma concentrations of S1P and aldosterone at week 42 were higher in CDthan in chow-fed SHRs (Fig. 5A and B). S1P only tended to correlate with aldosterone in a positive manner (Fig. 5C). To verify whether S1P-induced aldosterone release might be affected by obesity, we determined aldosterone plasma concentrations in response to S1P injections. Consistent with baseline levels after 42 weeks, aldosterone prior to i.v. S1P was higher in CD- than in chow-fed SHRs (Fig. 6A). Plasma aldosterone was affected by S1P (2-ANOVA: $P$ time $=0.0017$ ). In obese, but not in lean SHRs, a short-lasting increase in plasma aldosterone was observed. However, 2-ANOVA did not demonstrate any difference for diet ( $P$ diet $=0.179$, Fig. 6C). Despite higher glucose levels before S1P in the obese animals, S1P did not affect blood glucose either in lean or obese SHRs (Fig. 6B and D). In this experimental setting, S1P induced a short-lasting increase in MAP, showing no difference between lean and obese animals (Fig. 6E). S1PR mRNA levels in adrenal glands did not differ between chowand CD-fed rats. S1PR1 showed the highest and S1PR4 showed the lowest expression pattern. Interestingly, the S1PR3 expression was reduced in CD-fed rats (Table 1). S1PR5 receptor mRNA could not be detected.

Body weight differed between lean and obese Zucker rats ( $345 \pm 3$ vs $511 \pm 5 \mathrm{~g}, P<0.0001, n=11$ each group). In contrast to our findings in lean and obese SHRs, baseline aldosterone levels before S1P injection did not differ between lean and obese Zucker rats $(207 \pm 26$ vs $229 \pm 25 \mathrm{pg} / \mathrm{mL}, P=0.54)$. In response to vehicle and $100 \mu \mathrm{g} / \mathrm{kg}_{\mathrm{bw}} \mathrm{S} 1 \mathrm{P}$, aldosterone time dependently decreased in both lean and obese Zucker rats. After injecting 200 and more distinctly after $300 \mu \mathrm{g} / \mathrm{kg}_{\mathrm{bw}} \mathrm{S} 1 \mathrm{P}$, aldosterone exceeded both baseline and vehicle levels, particularly in the obese rats, as 2-ANOVA showed a statistically significant dose effect (Fig. 7A and B). In Zucker rats, S1Pinduced aldosterone release was not affected by obesity: the significance level was only 0.54 in 2-ANOVA testing of the corresponding AUCs of the lean vs obese Zucker rats. However, AUC values of obese Zucker rats treated with $300 \mathrm{ng} / \mathrm{mL}$ S1P were higher than those in animals receiving saline or $100 \mathrm{ng} / \mathrm{mL}$ S1P (Fig. 7C). This was not observed in lean animals.



\section{Figure 4}

Influence of $C D$ feeding on body weight $\left(A, P_{\text {time }}\right.$ 2-way Anova $\left.<0.0001\right)$, energy intake (B, Ptime 2-way ANova $<0.0001$ ), water intake (C, Ptime 2 -way ANOVA $<0.0001)$, blood pressure (D, Ptime 2-way ANova $<0.0001)$, heart rate (E, $P_{\text {time }}$ 2-way Anova $<0.002$ ) and blood glucose $\left(F, P_{\text {time }}{ }_{2 \text {-way Anova }}<0.0001\right)$ in SHRs. $P$-Values given in the figures originated from 2-ANOVA by testing the diet effects. $P$-Values given in legends originated from 2-ANOVA by testing the time effect. Bonferroni's post hoc test for multiple comparisons was only performed if $\mathrm{F}$ reached $P<0.05$ and there was no significant variance inhomogeneity. ${ }^{*} P<0.05$ vs controls tested by Bonferroni's post hoc test. Means \pm S.E.M., $n=12$ each group. 



\section{Discussion}

We clearly demonstrated that S1P dose dependently stimulates aldosterone release from adrenocortical cells by using S1P concentrations $>3 \mu \mathrm{M}$. We could also verify in the pithed rat model that S1P releases aldosterone via a direct humoral pathway in vivo. However, it remains uncertain as to whether S1P increases aldosterone release in obesity, thus acting as an MRF.

\section{S1P effects on aldosterone release in vitro}

It seems likely that S1PR1 dominates signaling: firstly, this receptor was found to be highly expressed compared to S1PR2, S1PR3 and S1PR4 in adrenals in our study and by others, too (Wang et al. 2014); secondly, aldosterone release was strongly stimulated by the specific and highaffinity S1PR1 agonist SEW2871 (EC $1306 \mathrm{nM})$, not activating S1PR2-5 even at a concentration of $10 \mu \mathrm{M}$ (Hale et al. 2004), and inhibited by the S1PR1 receptor antagonist W146 and FTY720 (Fig. 8). W146 specifically blocks S1PR1 (pKi 7.74) but not S1PR2, S1PR3 and S1PR5 (Sanna et al. 2006, Gonzalez-Cabrera et al. 2008). FTY720, established as fingolimod in treating multiple sclerosis, acts as a functional S1PR1 antagonist after sphingosine



\section{Figure 5}

Influence of CD feeding (for 42 weeks) on baseline plasma concentrations of S1P (A) and aldosterone (B) of SHRs. Means and upper and lower quartiles are depicted as boxplots. Whiskers indicate variability between the 10th and 90th percentiles; $* P<0.05$ chow vs CD after Student's $t$-test, $n=11$ each group. Correlation analysis between S1P and aldosterone (C) was performed by the 2-tailed Pearson test.

kinase-mediated conversion into FTY720-P. It binds at S1PR receptors and induces its internalization and degradation (Brinkmann 2009). As S1PR3 is closely related to S1PR1 in terms of evolution (Sanchez \& Hla 2004), we wanted to determine whether S1PR3 might also be involved. Indeed, the S1PR3 antagonist VPC02319 did lower aldosterone release (Fig. 8). However, VPC02319 unfavorably blocks not only S1PR3 but also S1PR1 (pKi values are 7.86 and 5.93 for S1PR1 and S1PR3 (Davis et al. 2005, Foss et al. 2007)), thus restricting any conclusion that a decrease in aldosterone secretion is related to S1PR3. To overcome this pharmacological disadvantage, the use of siRNA might represent an appropriate approach to selectively knockdown gene expression of S1PR1 and S1PR3 to clearly determine whether S1PR3 is also involved in aldosterone secretion (van Hooren et al. 2014, Li et al. 2015). We refrained from performing these experiments as (1) the knockdown efficacy (determined by qPCR or Western blots) was certainly not quantitative, thus limiting this genetic approach (van Hooren et al. 2014, Li et al. 2015), (2) the relevance of S1PR3 is suggested to be inferior compared to S1PR1 as its adrenal expression is sixfold lower (Table 1) and (3) our data support the findings of others, showing that aldosterone release stimulated by the S1PR1/R3 agonist VPC 24191 was completely abolished

A



B



$D$



http://joe.endocrinology-journals.org DOI: $10.1530 / J O E-16-0550$





Figure 6

Plasma concentrations of aldosterone and glucose before (A, B) and after S1P injection $\left(200 \mu \mathrm{g} / \mathrm{kg}_{\mathrm{bw}}\right)$ in chow- or CD-fed pithed SHRs. Means and upper and lower quartiles are depicted as boxplots. Whiskers indicate variability between the 10th and 90th percentiles. In line graph, data are expressed as means \pm S.E.M., ${ }^{*} P<0.05$ vs chow by Students $t$-test; ${ }^{+} P<0.05$ vs 0 by Wilcoxon Signed-Rank test or Student's $t$-test. 
Table 1 mRNA levels of S1P receptors in adrenal glands of chow- vs CD-fed SHRs. Means \pm S.E.M.

\begin{tabular}{|c|c|c|c|}
\hline $\begin{array}{l}\text { Copies/ng } \\
\text { RNA }\end{array}$ & $\begin{array}{l}\text { Chow-fed SHRs } \\
(n=10)\end{array}$ & CD-fed SHRs $(n=10)$ & $\boldsymbol{P}$ \\
\hline $\mathrm{S} 1 \mathrm{P} 1\left(\times 10^{3}\right)$ & $255.9 \pm 20.1$ & $227.5 \pm 19.1$ & 0.318 \\
\hline $\mathrm{S} 1 \mathrm{P} 2\left(\times 10^{3}\right)$ & $78.6 \pm 7.6$ & $69.4 \pm 7.6$ & 0.404 \\
\hline S1P3 $\left(\times 10^{3}\right)$ & $42.4 \pm 4.2$ & $31.6 \pm 2.7$ & 0.046 \\
\hline S1P4 $\left(\times 10^{3}\right)$ & $1.1 \pm 0.1$ & $1.2 \pm 0.1$ & 0.636 \\
\hline
\end{tabular}

by using VPC02319 (Brizuela et al. 2007) and that the expression of StAR protein was also enhanced after S1PR1/S1PR3 stimulation (Lucki et al. 2012) (Fig. 8). StAR is a transport protein that regulates cholesterol transfer within the mitochondria as the rate-limiting step in the production of steroid hormones. Accordingly, StAR protein and mRNA were elevated in parallel to adipocytestimulated aldosterone release (Krug et al. 2007). We, however, do concede that results obtained with VPC23019 should be interpreted with caution as suggested recently (Pyne \& Pyne 2011, Salomone \& Waeber 2011).

S1P enhanced aldosterone release to a lesser extent than forskolin or AngII. This may indicate that aldosterone release by S1P, AngII or forskolin stimulation is related to different signaling pathways. Forskolin and AngII act via the cAMP- or the PLC/IP3/DAG-dependent pathway, which both mobilize intracellular $\mathrm{Ca}^{2+}$ (Gambaryan et al. 2006), However, S1P - upon binding to the Gi proteincoupled S1PP1/S1PP3 - was claimed to activate not only PI3K/PKB (phosphatidylinositol 3-kinase/protein kinase B), but also MEK/ERK 1/2 (mitogen-activated protein kinase kinase/extracellularly regulated kinases 1/2), which further induces phospholipase D (PLD) activation. This corresponds nicely to the fact that MRF stimulates aldosterone release not via cAMP/PKA but rather via an ERK 1/2-related signaling pathway (Krug et al. 2007) (Fig. 8). Moreover, S1P causes calcium increase and activation of the PKC isoforms $\alpha$ and $\delta$, which are upstream of PLD (Brizuela et al. 2006, 2007).

Here, we show that S1PR2 exerts inhibitory properties on aldosterone release since the S1PR2 antagonist JTE013 increases aldosterone secretion (Fig. 8). JTE013 is a specific S1PR2 inhibitor (pKi 7.74) by not blocking S1PR1 and S1PR3, respectively (Ohmori et al. 2003, Parrill et al. 2004). As JTE013 was demonstrated to inhibit vasoconstriction not only to S1P, but also to the prostanoid analog U46619 or endothelin-1, it was claimed that JTE013 elicits its biological function independent of S1PR2 (Salomone \& Waeber 2011). However, we demonstrated here that JTE013 enhanced both baseline and S1P-induced aldosterone releases,
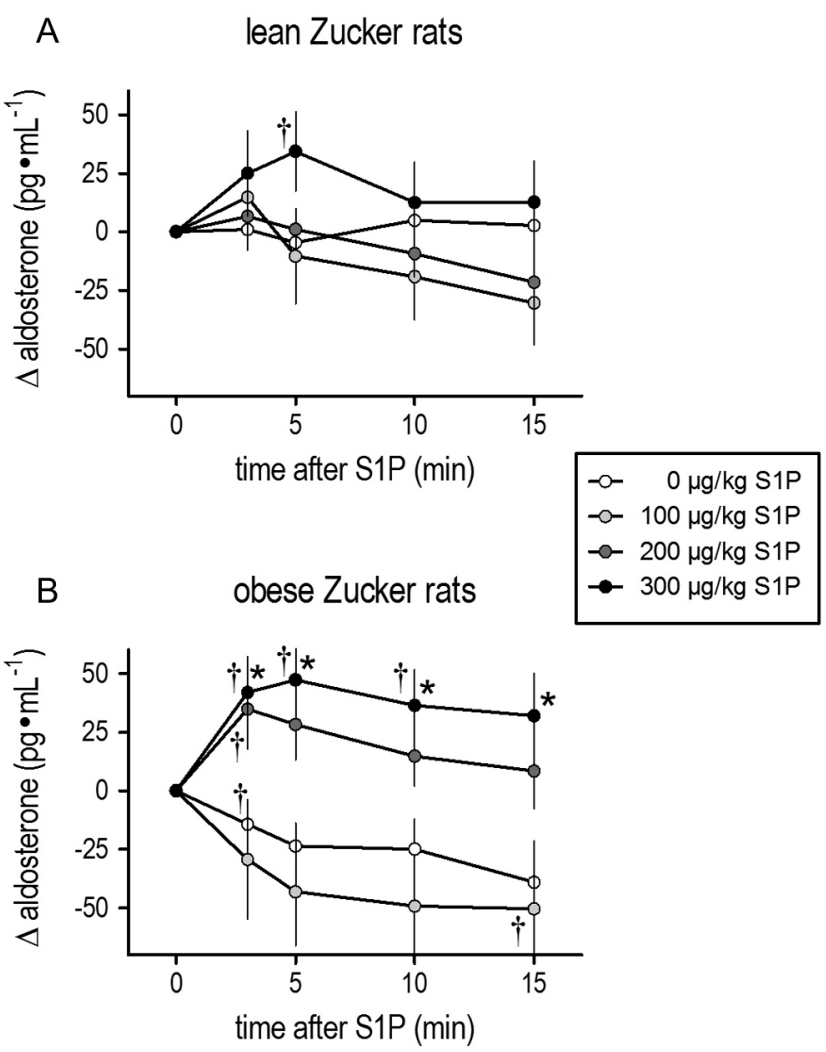

C

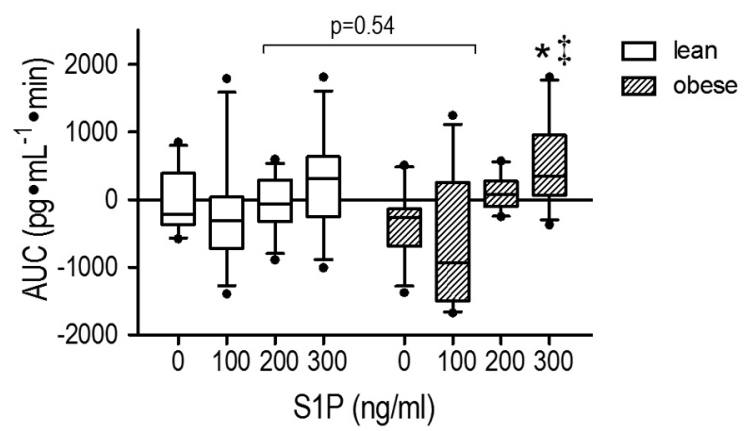

Figure 7

Aldosterone levels in response to S1P in lean $(A ; P S 1 P$ dose 2 -way ANovA $=0.420)$ and obese $\left(B ; P S 1 P\right.$ dose $\left._{2 \text {-way ANOVA }}=0.003\right)$ pithed Zucker rats. AUCS (C; PSIP dose 2 -way ANOVA $=0.001$ ) were calculated considering the delta values. In line graph, data are expressed as means \pm s.E.M. Means and upper and lower quartiles are depicted as boxplots. Whiskers indicate variability between the 10th and 90th percentiles. $P$-Values given in the figures originated from 2-ANOVA by testing the diet effects. $P$-Values given in legends originated from 2-ANOVA by testing the dose effect of S1P. ${ }^{+} P<0.05$ vs 0 by Wilcoxon Signed-Rank test; $* P<0.05$ vs $0 \mu \mathrm{g} / \mathrm{kg} \mathrm{S1P} \neq P<0.05$ vs $100 \mu \mathrm{g} / \mathrm{kg}$ S1P by Bonferroni's or Dunnet's post hoc test; $n=11$ each group.

thus strengthening the conclusion that the observed aldosterone response is dependent on S1PR2 and does not likely represent an S1P off target effect. Moreover, it was suggested that JTE013 has S1PR4 antagonistic properties (Pyne \& Pyne 2011). Considering that the adrenal

Published by Bioscientifica Ltd 

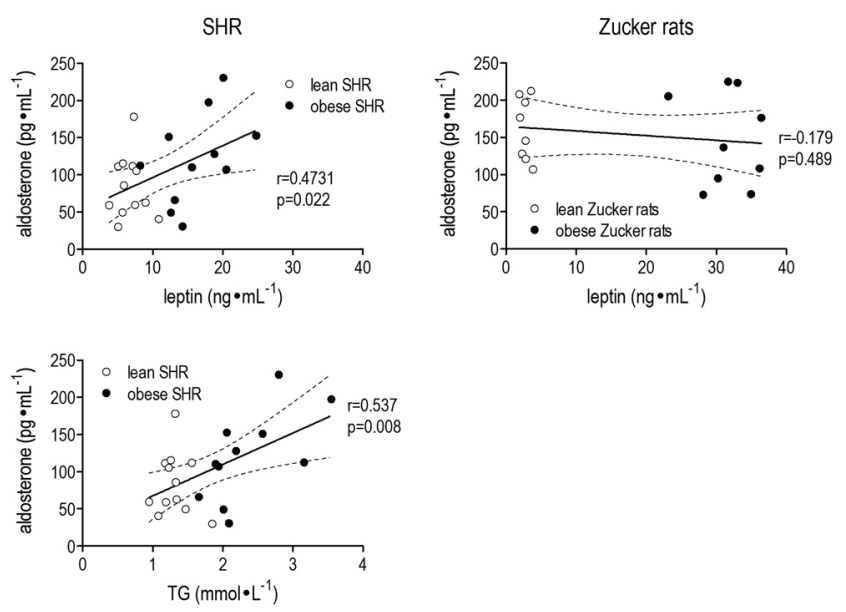

Figure 8

Effects of different S1PR subtypes on aldosterone sectretion: Aldosterone release is stimulated by the specific S1PR1 agonist SEW2871 and inhibited by the S1PR1 antagonist W146 and FTY720. VPC02319 lowered aldosterone release, suggesting a functional impact of S1PR3 as VPC02319 similarly blocks S1PR1 and S1PR3. The combination VPC02319+ JTE013 reduced S1P-induced aldosterone secreation, indicating that S1PR4 is also involved, considering, too, that S1PR4 is more likely to be expressed in adrenals than S1PR5. PI3K/PKB (phosphatidylinositol 3-kinase/protein kinase B); MEK/ERK 1/2 (mitogenactivated protein kinase kinase/extracellularly regulated kinases $1 / 2$ ); phospholipase D (PLD) activation; steroidogenic acute regulatory protein $(\mathrm{StAR}), \longrightarrow$ stimulation; $\vdash$ inhibition.

expression of S1PR4 is lower than that of S1PR2 (Table 1), however, we assume that its functional importance is also minor, which then does not necessarily require specific siRNA knockdown experiments to confirm the pharmacological results. Considering adrenal S1PR1 and S1PR2 expressions (shown here and in Wang et al. (2014)), both receptors might balance S1P-mediated aldosterone release. S1PR2 are $G_{i / o}$ but also $G_{q}$ and $\mathrm{G}_{12 / 13}$ coupled, which were thought to activate Rac and Rho, respectively, upon S1P stimulation (Brinkmann 2007). Endothelial barrier function was also shown to be regulated by the opposing effects of S1PR1 and S1PR2: while activation of S1PR1- $\mathrm{G}_{\mathrm{i} / \mathrm{o}}$ in endothelial cells stimulates Rac, thus increasing endothelial barrier function, stimulation of S1PR2-G $G_{12 / 13}$ activates the Rho pathway, thereby decreasing endothelial barrier function (Brinkmann 2007). The Rac/Rho pathways downstream at the initial activation of phospholipase $\mathrm{C}$ also mediate AngII-stimulated aldosterone release (Otis \& Gallo-Payet 2007).

Despite blocking S1PR1, SP1R2 and SP1R3, S1P incubation could still affect aldosterone release, thus suggesting that S1PR4 and S1PR5 play a role in regulating aldosterone. ERK1/2 signaling is activated by S1PR4 and inhibited by S1PR5 stimulation (Kluk \& Hla 2002). Hence, it seems more likely that reduction of aldosterone release - despite blockage of S1PR1, SP1R2 and SP1R3 - is associated with an S1PR4-related pathway (Fig. 8). The human NCI H295R cells do express S1PR5 but not S1PR4 (Ozbay et al. 2006), which, however, gives rise to doubts as to whether S1PR4-ERK1/2 stimulation actually leads to aldosterone release in our experiments. In contrast to Kluk and Hla, we detected low mRNA levels of S1PR4 in adrenals of rats, while S1PR5 fell below the detection limit.

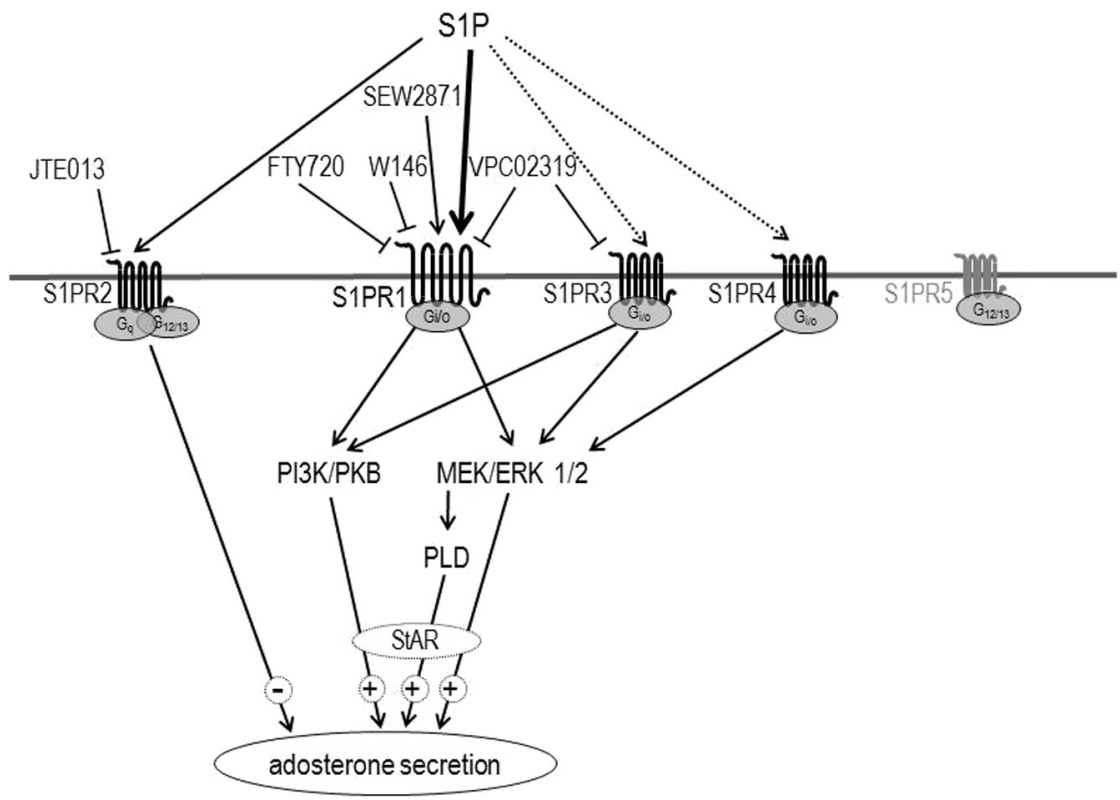

Figure 9

Correlation analyses between plasma levels of aldosterone and leptin and triglycerides (TG), respectively, from lean or obese spontaneous hypertensive rats (SHRs) or Zucker rats. Data originate from data previously published by our group (Müller-Fielitz et al. 2012a,b). http://joe.endocrinology-journals.org DOI: 10.1530/JOE-16-0550
๑) 2017 Society for Endocrinology Printed in Great Britain 


\section{S1P effects on plasma aldosterone in vivo}

In agreement with the literature (Lamounier-Zepter et al. 2006, Kidambi et al. 2007, Krug \& Ehrhart-Bornstein 2008), aldosterone plasma levels were found to be increased in obesity in our study (Figs 5 and 6). This was further suggested to be related to an enhanced sensitization of the adrenals toward AngII in obesity (Bentley-Lewis et al. 2007, Müller-Fielitz et al. 2012b) but also to an extra-adrenal mechanism as AngII-induced aldosterone release from adipocytes and Cyp11 12 mRNA expression were higher in isolated adipocytes from $\mathrm{db} / \mathrm{db}$ mice, thus provoking a greater amount of aldosterone release in vehicle, but not in candesartan-treated mice (Briones et al. 2012). However, as outlined in the introduction, MRF is not AngII (Ehrhart-Bornstein et al. 2003, 2004). Plasma aldosterone increased in response to $200 \mu \mathrm{g} / \mathrm{kg}_{\mathrm{bw}}$ S1P in lean SD rats, but not in lean SHRs, while lower S1P doses also lacked effects in SD rats. The extent of aldosterone release was markedly higher when SD rats were treated with AngII (Fig. 3). On the one hand, this supports our cell model results and suggests that S1P is an in vivo liberator of aldosterone, but, on the other hand, implies that the relevance of S1P as a modulator for aldosterone levels may be minor. Differences in S1Pstimulated aldosterone release between SD rats and SHRs might be attributed to distinct adrenal susceptibilities to various stimuli. Supporting this assumption, plasma renin activities and AngII plasma levels were demonstrated to be higher in SHRs than SD rats, while aldosterone levels were lower under low sodium conditions (Williams et al. 1982). In addition, AngII-stimulated aldosterone release was also markedly lower in isolated glomerulosa cells from SHRs than in SD rats, which indicates a decreased adrenal responsiveness to AngII (Williams et al. 1982).

Components of metabolic syndrome such as body weight, blood pressure and glucose levels were increased in rats in which obesity was a consequence of $\mathrm{CD}$ feeding or deficient leptin receptors. In our DIO rat model, plasma levels of S1P and aldosterone were simultaneously increased, while adrenal S1PR expression remained almost unchanged. This corresponds to studies in which elevated plasma levels of aldosterone (Lamounier-Zepter et al. 2006, Müller-Fielitz et al. 2012a) and S1P (Samad et al. 2006, Blachnio-Zabielska et al. 2012a,b, Kowalski et al. 2013, Choi \& Snider 2015) were observed. In addition to S1P, ceramides and sphingosine are also increased in plasma of obesity mice (Samad et al. 2006). Sphingosine is phosphorylated by the sphingosine kinase 1 (Sphk1) to form the bioactive S1P. Accordingly, Sphk1 mRNA expression and Sphk1 activity were found to be higher in white adipose tissue of obese rats than in lean controls (Tous et al. 2014). In particular, Sphk1 was assessed to be the crucial enzyme in regulating the balance between ceramides and S1P, both having opposite effects and involved in cell death or proliferation (Van Brocklyn \& Williams 2012). Regarding a functional context, a C18 ceramide-dependent mechanism was found to be involved in aldosterone-induced vascular endothelial cells (Zhang et al. 2016). However, C2 ceramide did not induce aldosterone secretion in bovine glomerulosa cells (Brizuela et al. 2006). So far, though, we do not know whether other ceramides lower aldosterone secretion.

The aldosterone response to S1P stimulus was only minor and short-lasting in CD-fed obese SHRs compared to their lean controls. Since adrenal susceptibility to S1P is thought to be low in SHRs, exogenously administered S1P might reasonably be less efficient. S1PR1 expression strengths were equal in lean and obese rats. Compared to saline, the S1P-stimulated aldosterone release was higher in obese than in lean Zucker rats but only by giving maximal doses of $300 \mu \mathrm{g} / \mathrm{kg}$. However, AUC analyses only showed low obesity-related S1P efficacy. Thus, we conclude that aldosterone release from adrenals or other sources (e.g., adipocytes) is not likely enhanced by S1P in obesity.

Obesity is a pervasive risk factor for oxidative stress and for cardiovascular diseases, too (Niemann et al. 2017). As reactive oxygen species can increase (Jin et al. 2004, Ader et al. 2008) or decrease (Gomez-Brouchet et al. 2007) Sphk1 activity, it may be speculated as to whether an obesitydependent increase in S1P might be related to oxidative stress, thus affecting aldosterone secretion. Considering that only the highest S1P levels increase aldosterone release in obese, but not in lean rats (Fig. 9), we conclude that this mechanism is only of minor importance. This assumption is strengthened by recent observations of the interaction between oxidative stress and aldosterone, showing that, in porcine adrenocortical cells, oxidative stress decreased mRNA levels of CYP11A1, CYP21 and 33-HSD, indicating a downregulation of aldosterone production (Wang et al. 2015). However, others have shown that mineralocorticoid receptor antagonism ameliorated elevated cardiac oxidative stress in obese Zucker rats (Bender et al. 2015) and prevented oxidative stress, but did not reduce weight gain after western diet in mice (Bostick et al. 2015). Furthermore, angiotensin II facilitated CYP11B2 activity and the ensuing aldosterone production via activation of the $\mathrm{AT}_{1}$ receptor-NADPH oxidase- $\mathrm{H}_{2} \mathrm{O}_{2}$ signaling pathway (Rajamohan et al. 2012).

Published by Bioscientifica Ltc. 
S1P seems thus rather unlikely to be MRF in obesity. Addressing this issue, others demonstrated that human adrenal ZG cells not only express leptin receptors but, moreover, that leptin increases aldosterone synthase expression and aldosterone production in mice. Obesitymediated hyperaldosteronism requires functional leptin receptors as both plasma aldosterone and adrenal CYP11B2 expression were increased in high fat dietfed, leptin receptor-deficient ( $\mathrm{db} / \mathrm{db})$ mice compared to regular diet-fed controls (Huby et al. 2015). We confirm the observation of Huby et al. that plasma levels of leptin and aldosterone correlate in $\mathrm{CD}$ - and chowfed SHRs but not in lean and obese Zucker rats (Fig. 8). However, data are inconclusive with regard to findings of the Bornstein group showing that leptin had no stimulatory effect on steroidogenesis in NCI H295R, thus concluding that leptin could not serve as the sought MRF (Ehrhart-Bornstein et al. 2003). Low-density lipoprotein (LDL) was found to increase aldosterone release in NCI H295R and to sensitize adrenocortical cells to AngII (Lamounier-Zepter et al. 2006). The fact that LDL was observed to be higher in obese than in lean hypertensive individuals further supports the idea of LDL acting as MRF (Lamounier-Zepter et al. 2006). Accordingly, very low-density lipoprotein (VLDL) also increased aldosterone secretion, expression of StAR protein and aldosterone synthase in NCI H295R cells (Xing et al. 2012). VLDL was suggested to stimulate aldosterone release in obesity since plasma levels of triglycerides - an indirect parameter to assess VLDL levels - positively correlated with CYP11B2 mRNA transcript levels in normal- and sucrose-diet groups (Xing et al. 2012). We again confirmed these in vitro findings by correlating TG and aldosterone levels in CD-fed and normally fed rats (Fig. 8).

In summary, S1P stimulates aldosterone release in vivo and in vitro predominantly via an S1PR1 pathway. However, S1P-induced aldosterone release was affected only slightly, if at all, in obesity, thus not supporting our hypothesis of S1P being a major player in hyperaldosteronism leading to obesity-induced hypertension.

\section{Declaration of interest}

The authors declare that there is no conflict of interest that could be perceived as prejudicing the impartiality of the research reported.

\section{Funding}

This research did not receive any specific grant from any funding agency in the public, commercial or not-for-profit sector.

\section{Author contribution statement}

$S \mathrm{~W}, \mathrm{HM}$ F and $\mathrm{W}$ R performed the research. W R and S W designed the research study. S W, H M F and W R analyzed the data and W R and S W wrote the paper.

\section{Acknowledgements}

The authors gratefully acknowledge Monika Ehrhart-Bornstein ( ${ }^{\dagger}$, Department of Internal Medicine III, Technische Universität Dresden, Dresden, Germany) for kindly providing them with the $\mathrm{NCI}$ H295R cell line, Annette Aufsess and Ines Stölting for technical assistance and Sherryl Sundell for improving the English style.

\section{References}

Ader I, Brizuela L, Bouquerel P, Malavaud B \& Cuvillier O 2008 Sphingosine kinase 1: a new modulator of hypoxia inducible factor 1alpha during hypoxia in human cancer cells. Cancer Research 68 8635-8642. (doi:10.1158/0008-5472.CAN-08-0917)

Bellini L, Campana M, Mahfouz R, Carlier A, Veret J, Magnan C, Hajduch E \& Le SH 2015 Targeting sphingolipid metabolism in the treatment of obesity/type 2 diabetes. Expert Opinion on Therapeutic Targets 19 1037-1050. (doi:10.1517/14728222. 2015.1028359)

Bender SB, DeMarco VG, Padilla J, Jenkins NT, Habibi J, Garro M, Pulakat L, Aroor AR, Jaffe IZ \& Sowers JR 2015 Mineralocorticoid receptor antagonism treats obesity-associated cardiac diastolic dysfunction. Hypertension 65 1082-1088. (doi:10.1161/ HYPERTENSIONAHA.114.04912)

Bentley-Lewis R, Adler GK, Perlstein T, Seely EW, Hopkins PN, Williams GH \& Garg R 2007 Body mass index predicts aldosterone production in normotensive adults on a high-salt diet. Journal of Clinical Endocrinology and Metabolism 92 4472-4475. (doi:10.1210/ jc.2007-1088)

Blachnio-Zabielska AU, Koutsari C, Tchkonia T \& Jensen MD $2012 a$ Sphingolipid content of human adipose tissue: relationship to adiponectin and insulin resistance. Obesity $202341-2347$. (doi:10.1038/oby.2012.126)

Blachnio-Zabielska AU, Pulka M, Baranowski M, Nikolajuk A, Zabielski P, Gorska M \& Gorski J 2012b Ceramide metabolism is affected by obesity and diabetes in human adipose tissue. Journal of Cellular Physiology 227 550-557. (doi:10.1002/jcp.22745)

Bloem LJ, Manatunga AK, Tewksbury DA \& Pratt JH 1995 The serum angiotensinogen concentration and variants of the angiotensinogen gene in white and black children. Journal of Clinical Investigation $\mathbf{9 5}$ 948-953. (doi:10.1172/JCI117803)

Borodzicz S, Czarzasta K, Kuch M \& Cudnoch-Jedrzejewska A 2015 Sphingolipids in cardiovascular diseases and metabolic disorders. Lipids in Health and Disease 14 55. (doi:10.1186/s12944-0150053-y)

Bostick B, Habibi J, DeMarco VG, Jia G, Domeier TL, Lambert MD, Aroor AR, Nistala R, Bender SB, Garro M, et al. 2015 Mineralocorticoid receptor blockade prevents Western diet-induced diastolic dysfunction in female mice. American Journal of Physiology: Heart and Circulatory Physiology 308 H1126-H1135. (doi:10.1152/ ajpheart.00898.2014)

Boustany CM, Bharadwaj K, Daugherty A, Brown DR, Randall DC $\&$ Cassis LA 2004 Activation of the systemic and adipose reninangiotensin system in rats with diet-induced obesity and hypertension. American Journal of Physiology: Regulatory, Integrative and Comparative Physiology 287 R943-R949. (doi:10.1152/ ajpregu.00265.2004)

Published by Bioscientifica Ltd 
Brinkmann V 2007 Sphingosine 1-phosphate receptors in health and disease: mechanistic insights from gene deletion studies and reverse pharmacology. Pharmacology and Therapeutics 115 84-105. (doi:10.1016/j.pharmthera.2007.04.006)

Brinkmann V 2009 FTY720 (fingolimod) in multiple sclerosis: therapeutic effects in the immune and the central nervous system. British Journal of Pharmacology 158 1173-1182. (doi:10.1111/j.14765381.2009.00451.x)

Briones AM, Nguyen Dinh CA, Callera GE, Yogi A, Burger D, He Y, Correa JW, Gagnon AM, Gomez-Sanchez CE, Gomez-Sanchez EP, et al. 2012 Adipocytes produce aldosterone through calcineurin-dependent signaling pathways: implications in diabetes mellitus-associated obesity and vascular dysfunction. Hypertension 59 1069-1078. (doi:10.1161/HYPERTENSIONAHA.111.190223)

Brizuela L, Rabano M, Pena A, Gangoiti P, Macarulla JM, Trueba M \& Gomez-Munoz A 2006 Sphingosine 1-phosphate: a novel stimulator of aldosterone secretion. Journal of Lipid Research 47 1238-1249. (doi:10.1194/jlr.M500510-JLR200)

Brizuela L, Rabano M, Gangoiti P, Narbona N, Macarulla JM, Trueba M \& Gomez-Munoz A 2007 Sphingosine-1-phosphate stimulates aldosterone secretion through a mechanism involving the PI3K/PKB and MEK/ERK 1/2 pathways. Journal of Lipid Research 48 2264-2274. (doi:10.1194/jlr.M700291-JLR200)

Van Brocklyn JR \& Williams JB 2012 The control of the balance between ceramide and sphingosine-1-phosphate by sphingosine kinase: oxidative stress and the seesaw of cell survival and death. Comparative Biochemistry and Physiology: Part B: Biochemistry and Molecular Biology 163 26-36. (doi:10.1016/j.cbpb.2012.05.006)

Butter JJ, Koopmans RP \& Michel MC 2005 A rapid and validated HPLC method to quantify sphingosine 1-phosphate in human plasma using solid-phase extraction followed by derivatization with fluorescence detection. Journal of Chromatography B: Analytical Technologies in the Biomedical and Life Sciences 824 65-70. (doi:10.1016/j. jchromb.2005.06.040)

Choi S \& Snider AJ 2015 Sphingolipids in high fat diet and obesityrelated diseases. Mediators of Inflammation 2015 article ID 520618 (doi:10.1155/2015/520618)

Cooper R, Forrester T, Ogunbiyi O \& Muffinda J 1998 Angiotensinogen levels and obesity in four black populations. ICSHIB Investigators. Journal of Hypertension 16 571-575. (doi:10.1097/00004872199816050-00003)

Davis MD, Clemens JJ, Macdonald TL \& Lynch KR 2005 Sphingosine 1-phosphate analogs as receptor antagonists. Journal of Biological Chemistry 280 9833-9841. (doi:10.1074/jbc.M412356200)

Ehrhart-Bornstein M, Lamounier-Zepter V, Schraven A, Langenbach J, Willenberg HS, Barthel A, Hauner H, McCann SM, Scherbaum WA \& Bornstein SR 2003 Human adipocytes secrete mineralocorticoid-releasing factors. PNAS 100 14211-14216. (doi:10.1073/pnas.2336140100)

Ehrhart-Bornstein M, Arakelyan K, Krug AW, Scherbaum WA \& Bornstein SR 2004 Fat cells may be the obesity-hypertension link: human adipogenic factors stimulate aldosterone secretion from adrenocortical cells. Endocrine Research 30 865-870. (doi:10.1081/ ERC-200044122)

Engeli S, Bohnke J, Gorzelniak K, Janke J, Schling P, Bader M, Luft FC $\&$ Sharma AM 2005 Weight loss and the renin-angiotensinaldosterone system. Hypertension 45 356-362. (doi:10.1161/01. HYP.0000154361.47683.d3)

Foss FW Jr, Snyder AH, Davis MD, Rouse M, Okusa MD, Lynch KR \& Macdonald TL 2007 Synthesis and biological evaluation of gammaaminophosphonates as potent, subtype-selective sphingosine 1-phosphate receptor agonists and antagonists. Bioorganic and Medicinal Chemistry 15 663-677. (doi:10.1016/j.bmc.2006.10.060)

Gambaryan S, Butt E, Tas P, Smolenski A, Allolio B \& Walter U 2006 Regulation of aldosterone production from zona glomerulosa cells by ANG II and cAMP: evidence for PKA-independent activation of CaMK by cAMP. American Journal of Physiology: Endocrinology and Metabolism 290 E423-E433. (doi:10.1152/ajpendo.00128.2005)

Garrison RJ, Kannel WB, Stokes J III \& Castelli WP 1987 Incidence and precursors of hypertension in young adults: the Framingham Offspring Study. Preventive Medicine 16 235-251. (doi:10.1016/00917435(87)90087-9)

Gembardt F, Heringer-Walther S, van Esch JH, Sterner-Kock A, van Veghel R, Le TH, Garrelds IM, Coffman TM, Danser AH, Schultheiss HP \& Walther T 2008 Cardiovascular phenotype of mice lacking all three subtypes of angiotensin II receptors. FASEB Journal 22 3068-3077. (doi:10.1096/fj.08-108316)

Giacchetti G, Faloia E, Mariniello B, Sardu C, Gatti C, Camilloni MA, Guerrieri M \& Mantero F 2002 Overexpression of the reninangiotensin system in human visceral adipose tissue in normal and overweight subjects. American Journal of Hypertension 15 381-388. (doi:10.1016/S0895-7061(02)02257-4)

Gomez-Brouchet A, Pchejetski D, Brizuela L, Garcia V, Altie MF, Maddelein ML, Delisle MB \& Cuvillier O 2007 Critical role for sphingosine kinase-1 in regulating survival of neuroblastoma cells exposed to amyloid-beta peptide. Molecular Pharmacology 72 341-349. (doi:10.1124/mol.106.033738)

Gonzalez-Cabrera PJ, Jo E, Sanna MG, Brown S, Leaf N, Marsolais D, Schaeffer MT, Chapman J, Cameron M, Guerrero M, et al. 2008 Full pharmacological efficacy of a novel S1P1 agonist that does not require S1P-like headgroup interactions. Molecular Pharmacology $\mathbf{7 4}$ 1308-1318. (doi:10.1124/mol.108.049783)

Hale JJ, Lynch CL, Neway W, Mills SG, Hajdu R, Keohane CA Rosenbach MJ, Milligan JA, Shei GJ, Parent SA, et al. 2004 A rational utilization of high-throughput screening affords selective, orally bioavailable 1-benzyl-3-carboxyazetidine sphingosine-1-phosphate-1 receptor agonists. Journal of Medicinal Chemistry 47 6662-6665. (doi:10.1021/jm0492507)

Harte A, McTernan P, Chetty R, Coppack S, Katz J, Smith S \& Kumar S 2005 Insulin-mediated upregulation of the renin angiotensin system in human subcutaneous adipocytes is reduced by rosiglitazone. Circulation 111 1954-1961. (doi:10.1161/01. CIR.0000161954.17870.5D)

van Hooren KW, Spijkers LJ, van BD, Fernandez-Borja M, Bierings R, van Buul JD, Alewijnse AE, Peters SL \& Voorberg J 2014 Sphingosine-1-phosphate receptor 3 mediates sphingosine1-phosphate induced release of weibel-palade bodies from endothelial cells. PLOS ONE 9 e91346. (doi:10.1371/journal. pone.0091346)

Huby AC, Antonova G, Groenendyk J, Gomez-Sanchez CE, Bollag WB, Filosa JA \& Belin de Chantemele EJ 2015 Adipocyte-derived hormone leptin is a direct regulator of aldosterone secretion, which promotes endothelial dysfunction and cardiac fibrosis. Circulation 132 2134-2145. (doi:10.1161/CIRCULATIONAHA.115.018226)

Igarashi J \& Michel T 2009 Sphingosine-1-phosphate and modulation of vascular tone. Cardiovascular Research 82 212-220. (doi:10.1093/cvr/ cvp064)

Jin ZQ, Goetzl EJ \& Karliner JS 2004 Sphingosine kinase activation mediates ischemic preconditioning in murine heart. Circulation 110 1980-1989. (doi:10.1161/01.CIR.0000143632.06471.93)

Karlsson C, Lindell K, Ottosson M, Sjostrom L, Carlsson B \& Carlsson LM 1998 Human adipose tissue expresses angiotensinogen and enzymes required for its conversion to angiotensin II. Journal of Clinical Endocrinology and Metabolism 83 3925-3929.

Kidambi S, Kotchen JM, Grim CE, Raff H, Mao J, Singh RJ \& Kotchen TA 2007 Association of adrenal steroids with hypertension and the metabolic syndrome in blacks. Hypertension 49 704-711. (doi:10.1161/01.HYP.0000253258.36141.c7)

Kluk MJ \& Hla T 2002 Signaling of sphingosine-1-phosphate via the S1P/ EDG-family of G-protein-coupled receptors. Biochimica et Biophysica Acta 1582 72-80. (doi:10.1016/S1388-1981(02)00139-7) http://joe.endocrinology-journals.org

DOI: 10.1530/JOE-16-0550
C 2017 Society for Endocrinology Printed in Great Britain 
Kowalski GM, Carey AL, Selathurai A, Kingwell BA \& Bruce CR 2013 Plasma sphingosine-1-phosphate is elevated in obesity. PLOS ONE 8 e72449. (doi:10.1371/journal.pone.0072449)

Krug AW \& Ehrhart-Bornstein M 2008 Aldosterone and metabolic syndrome: is increased aldosterone in metabolic syndrome patients an additional risk factor? Hypertension 51 1252-1258. (doi:10.1161/ HYPERTENSIONAHA.107.109439)

Krug AW, Vleugels K, Schinner S, Lamounier-Zepter V, Ziegler CG, Bornstein SR \& Ehrhart-Bornstein M 2007 Human adipocytes induce an ERK1/2 MAP kinases-mediated upregulation of steroidogenic acute regulatory protein (StAR) and an angiotensin II-sensitization in human adrenocortical cells. International Journal of Obesity $\mathbf{3 1}$ 1605-1616. (doi:10.1038/sj.ijo.0803642)

Lamounier-Zepter V, Rotthoff T, Ansurudeen I, Kopprasch S, Scherbaum WA, Ehrhart-Bornstein M \& Bornstein SR 2006 Increased aldosterone/renin quotient in obese hypertensive women: a novel role for low-density lipoproteins? Hormone and Metabolic Research 38 471-475. (doi:10.1055/s-2006-948137)

Li C, Li JN, Kays J, Guerrero M \& Nicol GD 2015 Sphingosine 1-phosphate enhances the excitability of rat sensory neurons through activation of sphingosine 1-phosphate receptors 1 and/or 3. Journal of Neuroinflammation 12 70. (doi:10.1186/s12974-015-0286-8)

Lucki NC, Li D \& Sewer MB 2012 Sphingosine-1-phosphate rapidly increases cortisol biosynthesis and the expression of genes involved in cholesterol uptake and transport in H295R adrenocortical cells. Molecular and Cellular Endocrinology 348 165-175. (doi:10.1016/j. mce.2011.08.003)

Maceyka M \& Spiegel S 2014 Sphingolipid metabolites in inflammatory disease. Nature 510 58-67. (doi:10.1038/nature13475)

Miesel A, Müller H, Thermann M, Heidbreder M, Dominiak P \& Raasch W 2010 Overfeeding-induced obesity in spontaneously hypertensive rats: an animal model of the human metabolic syndrome. Annals of Nutrition and Metabolism 56 127-142. (doi:10.1159/000278748)

Müller-Fielitz H, Landolt J, Heidbreder M, Werth S, Vogt FM, Jöhren O \& Raasch W 2012a Improved insulin sensitivity after long-term treatment with AT1 blockers is not associated with PPARgamma target gene regulation. Endocrinology 153 1103-1115. (doi:10.1210/en.20110183)

Müller-Fielitz H, Lau M, Jöhren O, Stellmacher F, Schwaninger M $\&$ Raasch W $2012 b$ Blood pressure response to angiotensin II is enhanced in obese Zucker rats and is attributed to an aldosteronedependent mechanism. British Journal of Pharmacology 166 2417-2429. (doi:10.111/j.1476-5381.2012.01953.x)

Müller-Fielitz H, Lau M, Geissler C, Werner L, Winkler M \& Raasch W 2015 Preventing leptin resistance by blocking angiotensin II AT1 receptors in diet-induced obese rats. British Journal of Pharmacology 172 857-868. (doi:10.1111/bph.12949)

Niemann B, Rohrbach S, Miller MR, Newby DE, Fuster V \& Kovacic JC 2017 Oxidative stress and cardiovascular risk: obesity, diabetes, smoking, and pollution: part 3 of a 3-part series. Journal of the American College of Cardiology 70 230-251. (doi:10.1016/j. jacc.2017.05.043)

Ohmori T, Yatomi Y, Osada M, Kazama F, Takafuta T, Ikeda H \& Ozaki Y 2003 Sphingosine 1-phosphate induces contraction of coronary artery smooth muscle cells via S1P2. Cardiovascular Research 58 170-177. (doi:10.1016/S0008-6363(03)00260-8)

Otis M \& Gallo-Payet N 2007 Role of MAPKs in angiotensin II-induced steroidogenesis in rat glomerulosa cells. Molecular and Cellular Endocrinology 265-266 126-130. (doi:10.1016/j.mce.2006.12.008)

Ozbay T, Rowan A, Leon A, Patel P \& Sewer MB 2006 Cyclic adenosine 5 '-monophosphate-dependent sphingosine-1-phosphate biosynthesis induces human CYP17 gene transcription by activating cleavage of sterol regulatory element binding protein 1. Endocrinology $\mathbf{1 4 7}$ 1427-1437. (doi:10.1210/en.2005-1091)
Parrill AL, Sardar VM \& Yuan H 2004 Sphingosine 1-phosphate and lysophosphatidic acid receptors: agonist and antagonist binding and progress toward development of receptor-specific ligands. Seminars in Cell and Developmental Biology 15 467-476. (doi:10.1016/j. semcdb.2004.05.006)

Proia RL \& Hla T 2015 Emerging biology of sphingosine-1-phosphate: its role in pathogenesis and therapy. Journal of Clinical Investigation 125 1379-1387. (doi:10.1172/JCI76369)

Pyne NJ \& Pyne S 2011 Selectivity and specificity of sphingosine 1-phosphate receptor ligands: "off-targets" or complex pharmacology? Frontiers in Pharmacology 2 26. (doi:10.3389/ fphar.2011.00026)

Raasch W, Bartels T, Schwartz C, Häuser W, Rütten H \& Dominiak P 2002 Regression of ventricular and vascular hypertrophy: are there differences between structurally different angiotensinconverting enzyme inhibitors? Journal of Hypertension 20 2495-2504. (doi:10.1097/00004872-200212000-00030)

Raasch W, Jungbluth B, Schäfer U, Häuser W \& Dominiak P 2003 Modification of noradrenaline release in pithed spontaneously hypertensive rats by I1-binding sites in addition to alpha2adrenoceptors. Journal of Pharmacology and Experimental Therapeutics 304 1063-1071. (doi:10.1124/jpet.102.044966)

Rahmouni K, Correia ML, Haynes WG \& Mark AL 2005 Obesityassociated hypertension: new insights into mechanisms. Hypertension 45 9-14. (doi:10.1161/01.HYP.0000151325.83008.b4)

Rajamohan SB, Raghuraman G, Prabhakar NR \& Kumar GK 2012 NADPH oxidase-derived $\mathrm{H}(2) \mathrm{O}(2)$ contributes to angiotensin II-induced aldosterone synthesis in human and rat adrenal cortical cells. Antioxidants and Redox Signaling 17 445-459. (doi:10.1089/ ars.2011.4176)

Salomone S \& Waeber C 2011 Selectivity and specificity of sphingosine1-phosphate receptor ligands: caveats and critical thinking in characterizing receptor-mediated effects. Frontiers in Pharmacology 29. (doi:10.3389/fphar.2011.00009)

Samad F, Hester KD, Yang G, Hannun YA \& Bielawski J 2006 Altered adipose and plasma sphingolipid metabolism in obesity: a potential mechanism for cardiovascular and metabolic risk. Diabetes $\mathbf{5 5}$ 2579-2587. (doi:10.2337/db06-0330)

Sanchez T \& Hla T 2004 Structural and functional characteristics of S1P receptors. Journal of Cellular Biochemistry 92 913-922. (doi:10.1002/ jcb.20127)

Sanna MG, Wang SK, Gonzalez-Cabrera PJ, Don A, Marsolais D, Matheu MP, Wei SH, Parker I, Jo E, Cheng WC, et al. 2006 Enhancement of capillary leakage and restoration of lymphocyte egress by a chiral S1P1 antagonist in vivo. Nature Chemical Biology 2 434-441. (doi:10.1038/nchembio804)

Sowers J, Tuck M, Asp ND \& Sollars E 1981 Plasma aldosterone and corticosterone responses to adrenocorticotropin, angiotensin, potassium, and stress in spontaneously hypertensive rats. Endocrinology 108 1216-1221. (doi:10.1210/endo-108-4-1216)

Tous M, Ferrer-Lorente R \& Badimon L 2014 Selective inhibition of sphingosine kinase- 1 protects adipose tissue against LPS-induced inflammatory response in Zucker diabetic fatty rats. American Journal of Physiology: Endocrinology and Metabolism 307 E437-E446. (doi:10.1152/ajpendo.00059.2014)

Wang C, Mao J, Redfield S, Mo Y, Lage JM \& Zhou X 2014 Systemic distribution, subcellular localization and differential expression of sphingosine-1-phosphate receptors in benign and malignant human tissues. Experimental and Molecular Pathology 97 259-265. (doi:10.1016/j.yexmp.2014.07.013)

Wang X, Wan D, Ihsan A, Liu Q, Cheng G, Li J, Liu Z \& Yuan Z 2015 Mechanism of adrenocortical toxicity induced by quinocetone and its bidesoxy-quinocetone metabolite in porcine adrenocortical cells in vitro. Food and Chemical Toxicology 84 115-124. (doi:10.1016/j. fct.2015.08.016) http://joe.endocrinology-journals.org

DOI: 10.1530/JOE-16-0550
๑ 2017 Society for Endocrinology Printed in Great Britain 
Williams GH, Braley LM \& Menachery A 1982 Decreased adrenal responsiveness to angiotensin II: a defect present in spontaneously hypertensive rats. A possible model of human essential hypertension. Journal of Clinical Investigation 69 31-37. (doi:10.1172/JCI110438)

Xing Y, Rainey WE, Apolzan JW, Francone OL, Harris RB \& Bollag WB 2012 Adrenal cell aldosterone production is stimulated by very-low- density lipoprotein (VLDL). Endocrinology 153 721-731. (doi:10.1210/ en.2011-1752)

Zhang Y, Pan Y, Bian Z, Chen P, Zhu S, Gu H, Guo L \& Hu C 2016

Ceramide production mediates aldosterone-induced human umbilical vein endothelial cell (HUVEC) damages. PLOS ONE 11 e0146944. (doi:10.1371/journal.pone.0146944)

Received in final form 6 September 2017

Accepted 26 September 2017
๑) 2017 Society for Endocrinology Printed in Great Britain
Published by Bioscientifica Ltd. 